\title{
Appropriate persistence in a project: the case of the Wine Culture and Tourism Centre in Bordeaux
}

\author{
Julien Cusin \\ Maître de Conférences \\ IAE Bordeaux, erm/IRGO \\ Pôle Universitaire de Sciences de Gestion \\ 35 , avenue Abadie \\ 33072 Bordeaux Cedex \\ Tél. : 0556009698 \\ E-mail : julien.cusin@u-bordeaux.fr
}

\author{
Juliette Passebois-Ducros \\ Maître de Conférences \\ IAE Bordeaux, erm/IRGO
}

Pôle Universitaire de Sciences de Gestion

35, avenue Abadie

33072 Bordeaux Cedex

Tél. : 0556009690

E-mail : juliette.ducros@u-bordeaux.fr

\begin{abstract}
Some authors view persistence as a negative attribute linked to the escalation of commitment, while others argue that perseverance is crucial to innovation. This paper seeks to explore the conditions in which persistence can be considered an appropriate strategy in the development of a project. To this end, we performed a qualitative and longitudinal study on the plan to open a Wine Culture and Tourism Centre in Bordeaux. The idea was first put forward in 1995. After experiencing a number of failures, the centre is now expected to open in 2016. We show that persistence can make sense: 1 ) if an emblematic leader makes the project a strategic priority and is able to command a consensus among the various stakeholders, 2) if the external environment changes and new choice opportunities emerge to revive the project, and 3) if the project marks a break with the past and is shored up by the success of similar projects.
\end{abstract}

Key words: persistence - escalation - project - failure - cultural installation 


\section{INTRODUCTION}

In an interview given in 2007, James Dyson, the inventor of the bagless vacuum cleaner, said that he designed 5,127 prototypes before hitting on the right one. Talking about the fifteen years (1979-1994) he spent testing his new product, he explained:

"I made 5,127 prototypes of my vacuum before I got it right. There were 5,126 failures. But I learned from each one. That's how I came up with a solution. So I don't mind failure [...]. It can take a very long time to develop interesting products and get them right. But our society has an instant-gratification thing. We admire instant brilliance, effortless brilliance. I think quite the reverse. You should admire the person who perseveres and slogs through and gets there in the end."1

Dyson's comments touch on the concept of persistence, a topic that has given rise to significant contributions in management studies. The concept of persistence encompasses a large body of literature, ranging from performance persistence of hedge funds and venture capital in the financial sector (Glode and Green, 2011; Cumming, Dai, Haß and Schweizer, 2012; Ammann, Huber and Schmid, 2013; Bredin, Cuthbertson, Nitzsche and Thomas, 2014; Hochberg, Ljungqvist and Vissing-Jørgensen, 2014) to persistence of innovation that deals with the sustainability of innovation over time in manufacturing firms (Roper and HewittDundas, 2008; Raymond, Mohnen, Palm and Schim van der Loeff, 2010; Bartoloni, 2012; Ganter and Hecker, 2013; Triguero and Corcoles, 2013; Suarez, 2014). The literature also includes numerous contributions on persistence in a failing course of action. While persistence is considered in a positive way in the first two categories of research, the third stream of studies paints a negative picture of the concept. Persistence in the face of negative results is often referred to as escalation of commitment (Staw, 1976, 1981; Ross and Staw, 1986; Brockner, 1992; Jani, 2011; Sleesman, Conlon, Mcnamara and Miles, 2012; Winch, 2013; Liang, Kale and Cherian, 2014; Schaumberg and Wiltermuth, 2014). In these articles, the authors study people who obstinately continue to invest time, money and self-identities into strategies and projects described as ineffective (Liang et al., 2014). Only studies on innovation management or championship behaviour adopt - at least implicitly - a positive

\footnotetext{
${ }^{1}$ Salter, C. (2007). Failure doesn't suck. Fast Company, $1^{\text {st }}$ May.
} 
view of perseverance, where the success of a new product is presented as the outcome of a generally fairly long, iterative, trial and error process, which involves not giving up at the first signs of failure (Van de Ven and Polley, 1992; Cheng and Van de Ven, 1996; Lynn, Morone and Paulson, 1996; Royer, 2001, Howell, Shea and Higgins, 2005; Walter, Parboteeah, Riesenhuber and Hoegl, 2011; Drummond, 2014). In many papers, the borderline between obstinacy (negative persistence) and tenacity (positive persistence) is somewhat blurred. Walter et al. (2011), for instance, demonstrated an inverted U-shaped relationship between persisting under adversity and organisational performance. However, we have no information about the maximum point of this curve. In short, in a failing course of action, decision-makers face a dilemma: do they quit (with the risk of missing an opportunity) or do they continue (with the risk of worsening the initial situation) (Drummond, 2014)?

Consequently, in the course of the process, decision-makers have to understand whether or not it is worth pursuing the efforts made to date if they find themselves facing a major setback. Our study therefore asks the following question: in what conditions is persistence an appropriate strategy in an organisation's project management? To answer our question, we performed a longitudinal study on the case of a tourist centre dedicated to wine culture: the Wine Culture and Tourism Centre (WCTC) in Bordeaux. Bordeaux is a French town, internationally reputed for its wine and seeking to reinforce its reputation through a large tourist facility. The project, emerging from a collective political will, was first launched in 1995 and, after a number of abortive attempts, will finally open in 2016. The project is interesting as it was developed within a latent organisation (Starkey, Barnatt and Tempest, 2000), with Bordeaux town council as the key player, rather than within a firm's traditional boundaries, as in the majority of innovation management studies. Moreover, the interest of this case study lies in the sector investigated. Despite the great diversity of major projects (Winch, 2013) studied, no research to date has focused on innovative projects in traditional 
and conservative sectors with a strong historical legacy, such as the wine industry in the city of Bordeaux. This approach seems promising as tradition could be viewed as a counterweight to persistence in the pursuit of an innovative action that has failed to date. Our findings point to three conditions for appropriate persistence in an organisation facing a situation of failure. We show how persisting with a project in the event of failure makes sense: 1) if an emblematic leader is able to command a consensus, 2) if the environmental conditions surrounding the project change and new choice opportunities appear and 3) if the project makes a break with the past and is legitimised by the success of other, similar projects.

\section{THEORETICAL BACKGROUND}

\subsection{PERSISTENCE IN THE FACE OF ADVERSITY PERCEIVED AS ESCALATION OF COMMITMENT}

Many studies suggest that individuals are tempted to pursue the prevailing actions they are publicly committed to, despite manifest proof that the latter should be discontinued (Staw, 1976, 1981; Ross and Staw, 1986; Biyalogorsky, Boulding and Staelin, 2006; Sleesman et al., 2012; Liang et al., 2014; Schaumberg and Wiltermuth, 2014). A well-known definition of escalation of commitment, a social psychology concept, is that of Brockner (1992: p. 40): "Escalation situations include repeated (rather than one-shot) decision making in the face of negative feedback about prior resource allocations, uncertainty surrounding the likelihood of goal attainment, and choice about whether to continue." As Winch (2013) suggested, escalation of commitment is a temporal process driven by the dynamic interplay of projectrelated, psychological, social and structural factors (Staw and Ross, 1987). Firstly, projectrelated factors include elements such as the cost/benefit comparison of pursuing or terminating the project (Northcraft and Wolf, 1984; Liang et al., 2014), the magnitude of fixed costs linked to pulling out, and the inherent difficulties in redeploying specific assets 
(Delios, Inkpen and Ross, 2004) or in evaluating the project's real performance (Bowen, 1987). In effect, in an ambiguous situation, the difference between success and failure is not always obvious (Levitt and March, 1988), making it difficult to define the limits beyond which a project should be considered as unacceptable (Bowen, 1987). Secondly, escalation of commitment is related to psychological factors. Cognitive factors correspond principally to any information processing that falls short of the hypothesis of perfect rationality. For example, the human tendency to put failure down to external and temporary causes could short-circuit potential organisational learning and lead to greater likelihood of persistence (Staw, 1981; Lant, Miliken and Batra, 1992; Winch, 2013). Similarly, Jani (2011: p. 935) noted that "individuals with high self-efficacy, built upon a history of past successes, are more likely to persist with a failing course of action as they may continue to believe that they can turn around the failing situation." Emotions also influence escalation behaviours. For instance, anticipated regret about project withdrawal is positively related to escalation of commitment (Liang et al., 2014). Thirdly, social factors must also be taken into account to understand escalation of commitment behaviour. For example, maintaining an initial strategy, despite negative signals, allows the stakeholders not to lose face (Brockner, 1992; Biyalogorsky et al., 2006; Kisfalvi, 2000; Schaumberg and Wiltermuth, 2014) as retraction is often culturally perceived as a sign of weakness on the part of a leader (Choo, 2005). Staw (1976) effectively showed how hard it is to take a decision that could be interpreted as an admission of a past mistake. Finally, as Staw and Ross (1987) suggested, escalation of commitment may also be explained by structural factors that reflect the institutionalisation of a project within an organisation. Indeed, the project may well already have had a significant impact on the organisation (e.g.: creation of a new department) or have internal political support. This last argument highlights an important point, namely that escalation of commitment in a major project is seldom an individual decision but is more likely to be a 
multiparty event (Vit, 2011; Liang et al., 2014). The phenomenon should thus be considered in its own socioeconomic context. One way to do this would be to study the interaction between all of the stakeholders. Furthermore, when investigating escalation of commitment in a project, we should keep in mind that those responsible for planning and authorizing the project may well have moved on (Drummond, 2014). Thus, longitudinal case studies implemented over time are useful to analyse this kind of behaviour since persistence certainly changes in nature when it involves different actors over a long period. An in-depth case study, integrating the socio-economic context, seems all the more important in that various papers have suggested that national culture influences the propensity to persist. According to the literature, Chinese and Mexican subjects are more likely to escalate their commitment than their U.S. counterparts (Liang et al., 2014), for instance. This is perhaps why persisting in the face of negative results is perceived so negatively in the USA, where the idea of "fail fast, fail often" (Babineaux and Krumboltz, 2013) is frequently defended. This implies that failure is socially accepted in the USA, but that individuals should not insist in the face of adversity. Is this behaviour always appropriate? Could the organisation be missing great opportunities in this way? Such questions are definitely worth raising.

\subsection{EXTENSION TO THE CONCEPT OF PERSISTENCE IN A FAILING COURSE OF ACTION}

The literature suggests that persisting in a failing course of action is inappropriate for the organisation. Escalation of commitment implies economically non-rational behaviour, even if, strictly speaking, this does not mean that the outcomes of the said actions will ultimately be bad (Brockner, 1992; Royer, 2001, 2003; Staw, 1981). The position of persistence in the face of adversity nonetheless tends to be viewed in a negative light in the literature, as the additional resources allocated to an ailing project increase the organisation's financial losses (Ross and Staw, 1986; Royer, 2001, 2003; Staw, 1976). Thus, escalation of commitment is 
often described as a problem (Jani, 2011), a decision error (Winch, 2013), a failed organisational decision (Sleesman et al., 2012) or as a behavioural pattern of throwing good money after bad (Drummond, 2014). And yet the virtues of perseverance are also found in popular wisdom, summed up in the old saying: "If at first you don't succeed, try, try, again" (Sandelands, Brockner and Glynn, 1988: p. 208). Thus, the common understanding of persistence reflects not only obstinacy, as found in the current state of the art, but also tenacity and determination. Although the term persistence is rarely used, the idea is implicit in many studies on innovation management, especially ones that present the latter as an iterative trial and error process (Maidique and Zirger, 1985; Lynn et al., 1996). ${ }^{2}$ According to these authors, pursuing an action in the face of adversity is truly positive and even heroic behaviour, and is even viewed as a paramount condition for the success of radical innovations (Schon, 1963; Royer, 2001, Howell et al., 2005). For instance, Walter et al. (2011) argued that innovation champions display four behaviours, including persisting under adversity. Unlike some work on escalation of commitment, such arguments suggest that persistence can be beneficial for a project up to a point. "Such persistence is necessary as the champion fights the many challenges and hurdles (e.g.: bureaucratic hurdles, resistance to change from others, justified ambivalence) to garner the necessary support (resource, expertise, etc.) to make the idea a commercial success" (Walter et al., 2011: p. 591). More precisely, the authors argue that there is an inverted U-shaped relationship between persisting under adversity and organizational performance. The challenge for decision-makers is thus to position the cursor correctly. To what extent is the decision to persist appropriate? The authors are silent on this point. Although the literature on innovation management does not answer this crucial question, it does argue that persisting in a failing course of action can be positive to a certain extent. Indeed, many studies on innovation management suggest that action clarifies thinking in a

\footnotetext{
${ }^{2}$ The term persistence is used by Lynn et al. (1996: p. 31). However, it is not conceptualised in any way, and is applied in the commonly understood sense.
} 
situation of uncertainty (Van de Ven and Polley, 1992; Cheng and Van de Ven, 1996; Lynn et al., 1996; Thomke, von Hippel and Franke, 1998). In this sense, pursuing an action that got off to a bad start is seen as a way to reduce market uncertainty. Thus, the organisation gradually tweaks the technical and commercial aspects of its project in line with the data obtained from market trials (Cheng and Van de Ven, 1996; Lynn et al., 1996). Most failed product launches thus form an important stage in an innovative firm's development strategy, as mistakes made in the course of a project are used to improve the development of future products (Maidique and Zirger, 1985; Meyers and Wilemon, 1989; Townsend, 2010). In such conditions, the strategic challenge for an organisation is not to succeed with one isolated project, but rather to construct an original and sustainable trajectory of successive innovations (Nemanich, Keller and Vera, 2007; Suarez, 2014). ${ }^{3}$ However, the probe and learn process is a very long and costly way of reducing uncertainty. Motorola, for instance, spent 15 years and 150 million dollars before launching cell phones onto the market (Lynn et al., 1996). Such behaviour is risky, because environmental uncertainty makes it is very difficult to know if an organisation is engaged on a successful or a disastrous path in the course of the process, and whether or not it should persist (Lant et al., 1992). March and Shapira (1987) noted that it is difficult to differentiate ex-ante between, on the one hand, someone who explores risky concepts that turn out to be dead ends (the mad fool) and, on the other, someone who challenges established patterns to find themselves at the origin of a welcome disruptive innovation for the organisation (the visionary genius). Ex-post, there is an obvious risk of retrospective rationalisation: observers will tend to speak about tenacity when persistence ends in success (probe and learn approach) and obstinacy when it ends in failure (escalation of commitment). "We must not believe for a moment those edifying stories which

\footnotetext{
3 We speak about an innovation path (or innovation trajectory) when there is a deliberate linkage - i.e. an interweaving - between several consecutive projects within a same organisation (e.g.: same commercial target) that results in dynamic inter-project learning.
} 
retrospectively invoke [all the explanations for failure] [...]. All of these are true, banally so, but they are of a truth blindly created by the story. Doctus post factum," Akrich, Callon and Latour (2002a: p. 190) noted in this regard.

In situations of adversity, project leaders face a dilemma: does they quit or continue (Drummond, 2014)? Drummond (2014) argued that the literature mainly focuses on the risk of escalation, but that very few studies mention the opposite error, i.e. the risk of abandoning a potentially successful project too soon. Indeed, she suggests that in some cases the organisation should press on the accelerator despite the difficulties encountered.

Unfortunately, as the author deplored, "there has been little synthesis of the conceptual tools or heuristics that might help an organisation stay the course when it is wise to do so" (Drummond, 2014: p. 435). According to Jani (2011), project managers are less likely to continue with failing projects if they have a clear idea of the project risks. This view is somewhat surprising as it implicitly relies upon a heroic notion of decision-making (Winch, 2013). Risk identification, risk classification and risk evaluation are far from simple. In this regard, we should recall that risk perception depends on the individual's ability to control project variables that can impact on the project's success. In practice, project managers are likely to underestimate the risks of a project with endogenous risk factors as compared to a project with exogenous risk factors due to their greater degree of perceived controllability over the endogenous risk factors (Jani, 2011). It is therefore up to the individual to decide whether or not to persist, i.e. to know if the maximum point of the inverted U-shaped curve mentioned by Walter et al. (2011) has been reached (or not). The boundary between a promising project and a failing project is often enigmatic. Thus, there is often a retrospective rationalisation in studies that suggest that individuals persisted for too long before abandoning 
projects with poor prospects of success (Heng, Tan and Wei 2003). If forecasting in a context of uncertainty was so simple, the new project failure rate would not be so high. ${ }^{4}$

Should the attempt by Lynn et al. (1996) to explain the success of General Electric, Motorola, IBM and Corning by what they learnt from their past failures be seen as a form of rationalisation a posteriori, for instance? The company leaders studied by the authors were all convinced of the relevance of their concept and continued to invest resources for many years, despite the negative market feedback. Their tenacity paid off, as each narrative turns out to be a success story. However, the starting point for this study is not failure as such (to see if a frustrating setback subsequently leads to organisational learning), but rather success, which the authors then justify, in a backward-reasoning process, by the firm's past failures. The approach adopted thus appears to be a disguised form of exampling, since the cases were selected to confirm the initial idea. However, from a managerial perspective, it is of little interest to say a posteriori that persistence is appropriate since it led to success. Decisionmakers need to know whether or not to pursue their goal in the course of the process. To our knowledge, the only criteria advanced in the literature in this respect come from Lynn et al. (1996), who argue that persisting in a given trajectory is a priori positive, despite potential negative signals from the environment, if this decision is underpinned from the outset by a clear strategic vision on the part of the leader. For example, the development of cell phones at Motorola began not long after the firm started to define itself as a specialist in mobile communications. The cell phone was thus a logical step after the launch of the first mobile radios, followed by portable radios and then pagers. The aim of the present study is to explore this issue in more depth and to contribute new input to the discussion. More specifically, we ask the following question: in what conditions is persistence an appropriate strategy in an organisation's project management?

\footnotetext{
4 "Product failure rates have been variously reported in the range of 40\% to 90\%" (Liang et al., 2014: p. 155).
} 
In other words, our aim is not to know whether a given project will ultimately succeed or fail, but rather to identify factual elements during the project lifespan that are perceived by the decision-maker as justifying further effort despite adversity. Our interest is uniquely in the decision to persist, based on the information available at that specific time. A decision to persist can thus be considered appropriate (or not), regardless of the final project outcome in terms of effective launch or economic success. In this way, we investigate the issue of persistence from a more realistic angle by focusing on the dilemma faced by the decisionmaker.

\section{METHODOLOGY}

\subsection{EMPIRICAL SETTING}

We conducted a longitudinal case study on a scheme developed by the town council to open a Wine Culture and Tourism Centre (WCTC) in Bordeaux. Our aim is to fill the gap identified by Brockner (1992) and Kisfalvi (2000) regarding the lack of in situ and long-term field studies on escalation of commitment. To date, studies with an implicitly positive view of persistence have tended to only include organisations operating according to the paradigm, criticised by Chesbrough (2003), of closed innovation (e.g.: Apple, IBM, Motorola, etc.). However, Sydow (2009) suggested that projects can also be developed outside the traditional boundaries of a firm, within what Starkey et al. (2000) called latent organisations. These networks draw key players around a central core in ongoing relationships that surface when new projects emerge. Finally, while studies on persistence in a failing course of action place strong emphasis on qualitative methods in the wide range of sectors investigated, ${ }^{5}$ no research

\footnotetext{
${ }^{5}$ The most famous cases studied are: the Channel Fixed Link (Winch, 2013), Expo '86 in Vancouver (Ross and Staw, 1986), the Shoreham Nuclear Power Plant on Long Island (Ross and Staw, 1993), and the Taurus information technology project for the London Stock Exchange (Drummond, 1996). In the press, there also
} 
to date has examined innovative projects in traditional and conservative sectors with a strong historical legacy, such as the wine industry in the city of Bordeaux.

The Wine Culture and Tourism Centre in Bordeaux, was designed to develop mainstream awareness of the culture of wine and to promote wine tourism in Aquitaine. It was launched in 1995 during Alain Juppé's first mandate as mayor and, after experiencing a number of setbacks, is finally scheduled to open in 2016. We should add that with respect to our research question, it was important to study an ongoing project so as to avoid the risk of a posteriori rationalisation, as mentioned above in the study by Lynn et al. (1996). In effect, we did not want the study to focus on elements that were only evident at the end of the process. As Akrich et al. (2002a: p. 191) noted, "while the management of innovation literature fills entire libraries, the case studies which avoid the trap of retrospective explanation still remain scant." In concrete terms, we contacted the director of WCTC to present our research topic in October 2011, almost a year before the project was finally accepted. In addition, all the interviews we conducted (see below) took place before its official acceptance. Moreover, even today there is no proof that the WCTC will be the flagship centre that Bordeaux hopes for in 2016. In other words, there was absolutely no indication that the project would come to a positive conclusion when we first got involved. That is exactly why we selected this particular project rather than another of the major projects in the town that were also slow to emerge but today are considered a success (e.g., the Institut des Sciences de la Vigne et du Vin). ${ }^{6}$

stories about the U.S. Air Force's new combat support system, the Fresh and Easy brand from Tesco, and the highway construction project in Boston (Sleesman et al., 2012; Drummond, 2014).

6 The ISVV covers all the research, training and technology transfer teams in the wine-making sector in Bordeaux: http://www.univ-bordeauxsegalen.fr. 


\subsection{DATA COLLECTION AND ANALYSIS}

To analyse the way project managers take decisions and the impact these choices can have on project outcomes, an in-depth long-term study was considered the most suitable (Van Oorschot, Akkermans, Sengupta and van Wassenhove, 2013). This type of process-based study is perfectly suited to our research question (Langley, 1999; Langley, Smallman, Tsoukas and Van de Ven, 2013). Consequently, we followed recommendations by Ann Langley in our analysis structure, at the same time adopting two research strategies. First, we used a narrative strategy, charting the WCTC project milestones in detail and in chronological order. This helped us to contextualise the case (nature of the project, challenges, key players, support, resistance, etc.) and to identify the main milestones in the project's history. As Garud, Kumaraswamy and Peter Karnøe (2010: p. 768) explained, “many researchers dismiss narratives as being stories or case studies that do not possess the stamp of scientific rationality. However [...] narratives are fundamental mechanisms for the dynamic patterning of actors and artefacts." Thus, in their research on path dependency - a concept similar to persistence in a failing course of action (Dobusch and Schüßler, 2012) - Garud et al. (2010) recommended a narrative approach. In similar vein, Denis, Dompierre, Langley and Rouleau (2011) also examined the phenomenon of escalation through a case history. In addition to the narrative strategy, we also adopted a strategy of temporal bracketing, in other words, we identified various sequences within the ongoing project phases, which were defined by determining the discontinuities (Langley et al., 2013). Langley (1999) commented that such sequences should not be confused with successive phases of a process, but should simply give structure to the description of facts.

This analytical narration methodology requires a rich and varied corpus of data. We thus conducted 11 semi-directive interviews with players closely linked to the project between March and September 2012, each lasting over an hour on average (cf. Table 1). 


\section{[Insert Table 1 about here]}

Obviously, a process-based study cannot be based on retrospective interviews alone, as these tend to overwrite the chronology of events: "Longitudinal data [...] are necessary to observe how processes unfold over time. Archival data [...] are particularly suitable for tracing event chronologies, meanings, and discourses over long or very long periods of time" (Langley et al., 2013: p. 6). Thus, we collected 16 official reports concerning the different projects for the wine and wine tourism cultural centre, written between 1995 and 2012. In addition, we collected 28 press articles (mainly local) that were also very useful to our study (cf. Table 2).

\section{[Insert Table 2 about here]}

It is important to point out that we collected all these secondary data (data prior to 2012) before starting the interviews. Being able to pick up on the answers of our respondents on the basis of this information made the data collection far more accurate, significantly reducing the recall bias. In addition, it was important for some of the actors to be interviewed with a little hindsight. For instance, the first project manager (cf. Table 1) admitted that she would not have been emotionally ready to answer our questions a few years earlier.

The construction of a chronological narrative structured by critical moments (see the first two sections of the empirical analysis below), as used in our methodological approach, corresponds only to a first order analysis (Gioia, Corley and Hamilton, 2012) as, at this stage, it uses the terms and codes of the respondents. Our empirical analysis was thus followed by a second order analysis (Gioia et al., 2012) that enabled us not only to introduce concepts, topics and dimensions from our review of the literature, but also new aspects in line with an abductive approach (see the third section of the empirical analysis below). It should be noted however that, unlike Gioia et al. (2012), we do not insist on grounded theory. Indeed, the interpretive coding (Miles and Huberman, 1994) we performed in this paper is based on dimensions from both the literature (uncertainty, adversity, repeated investment, self- 
justification, etc.) and the case study (direct and indirect experience feedback, unlearning, leadership, choice opportunities, etc.). The Word file obtained from this study totals 52 singlespaced pages in all.

\section{EMPIRICAL ANALYSIS}

In this section, we present the analysis of our empirical data (spanning almost 20 years) in the form of a chronological narrative, structuring it according to the main milestones. During the data coding stage, it became obvious that the different mandates of the mayor of Bordeaux, Alain Juppé, corresponded to key events in the temporal breakdown of the WCTC project. Consequently, it seems useful to precede the narration with a brief reminder of the political situation in Bordeaux. ${ }^{7}$ This shows that Alain Juppé has always been elected in the first round of voting with an ever-increasing score that has strengthened his leadership over time.

19 October 1947 - 19 June 1995: Successive mandates of Jacques Chaban-Delmas 19 June 1995 - 11 March 2001: Alain Juppé's $1^{\text {st }}$ mandate ( $1^{\text {st }}$ round - $50.28 \%$ of votes) 11 March 2001 - 13 December 2004: Alain Juppé's $2^{\text {nd }}$ mandate ( $1^{\text {st }}$ round - 50.96\% of votes) Mandate interrupted by Alain Juppé's conviction for a fictitious jobs scandal at the Mairie of Paris. His deputy took over from him.

8 October 2006 - 9 March 2008: Alain Juppé's $3^{\text {rd }}$ mandate ( $1^{\text {st }}$ round $-56.24 \%$ of votes)

Municipal by-election triggered by the resignation of the majority following Alain Juppé's decision to make a political comeback after his period of ineligibility.

9 March 2008 - March 2014: Alain Juppé's $4^{\text {th }}$ mandate ( $1^{\text {st }}$ round $-56.62 \%$ of votes)

$\underline{23 \text { March } 2014 \text { to present: }}$ Alain Juppé's $5^{\text {th }}$ mandate ( $1^{\text {st }}$ round $-60.95 \%$ of votes)

\subsection{FAILURE OF THE FIRST WINE CULTURE AND TOURISM CENTRE PROJECT (1995-2007)}

When Alain Juppé was first elected in Bordeaux in 1995, he took over from a 48-year term in office by the former mayor, thus marking a new age in the city's political history. He rapidly began some major urban redevelopment work (refurbishment of façades, restructuring of the port area, tramway, etc.) that inevitably impacted on the $18^{\text {th }}$ century urban heritage. Instead of demolishing the Luze wine cellars in the heart of the historic Chartrons district, in July 1995, a local association suggested using them for a cultural centre dedicated to Bordeaux

\footnotetext{
${ }^{7}$ http://fr.wikipedia.org/wiki/Alain Jupp $\% \mathrm{C} 3 \% \mathrm{~A} 9$
} 
wines as a testimonial to the district's prestigious past. The new mayor of Bordeaux immediately became interested in the project and commissioned a cultural engineer, Catherine Arteau, to conduct several studies. The idea of developing a cultural centre rapidly emerged. While the project outline was clearly defined thanks to the intervention of experts (interior designer, designer, stage designer, graphic designer, economist, etc.), the economic dimension gradually crept in over time. In 1998, Catherine Arteau stated that the aim of the scheme was to create a major structure that would contribute to Bordeaux's tourist attractions whilst consolidating its image as the world's wine capital. In particular, she introduced the vineyard indicator platform concept in a bid to make the WCTC a gateway to the Bordeaux vineyards. The project soon came up against issues of accessibility and the functionality of the Chartrons site (e.g.: parking problems). Instead of abandoning the idea, however, a warehouse on the Quais de la Garonne was proposed as an alternative site. ${ }^{8}$ During a meeting called by the mayor of Bordeaux on 17 December 1998, the project's interest was reiterated. The municipality earmarked a 3 million euro budget for the scheme (with an estimated total cost of 13 million euros). Unfortunately, the final feasibility stage, in other words, backing from one or several potential operators to build and manage the multi-site complex under the agreed conditions failed to materialize. Despite this setback, Alain Juppé remained enthusiastic, unlike the wine sector professionals who remained relatively sceptical about the idea of wine tourism. During his $2^{\text {nd }}$ term in office in 2001, the project was given to a town councillor to manage, and the latter continued working within the framework drawn up by Catherine Arteau.

"[The deputy Mayor] handed me [the project] telling me: 'Listen, we've made good headway. The project is pretty clear concerning its construction [on the Chartrons site]' [...]. Personally, I took on the project because I was asked to do it, without actually having had anything to do with the decision-making [...]. At the beginning, the project was managed by [Catherine Arteau], so I carried on from where she left off." [POT]

\footnotetext{
${ }^{8}$ The new global Luze wine cellar (cultural centre) + warehouse (shopping centre) project was called "Le Monde du Vin" (the world of wine) in a new study conducted by Catherine Arteau in 2000.
} 
The councillor was asked to find private partners to finance the centre and to manage it.

Despite discussions with a cultural projects coordinator, there was no response to the call to tender, due to a lack of financial support from the local authorities. In 2004, only the mayor of Bordeaux was ready to commit between 1,525 and 1.75 million euros (with a total budget of around 6 million euros). Alain Juppé's second term was thus marked by a new setback for the project that the wine producers continued to eschew. In 2004, it had come to a standstill and the abrupt end to Alain Juppé's mandate appeared to sound its death knell.

\begin{abstract}
"I began to look for partners. I found a very reliable partner, Culturespaces, who expressed a real interest in managing the operation [and] making a financial contribution. I submitted the project as it was [with largely private funding...]. [The project] couldn't be signed as it stood! So the call to tender that we launched to find partners came to nothing. And so it kind of stopped there [...]. The council was not willing to invest more than a million and a half euros at that time. The investment was very small [...]. And the private partners who were supposed to invest were simply not around [...]. Culturespaces wanted to go ahead [and was ready to invest] a million euros, if my memory serves me well. It wasn't enough! [...]. At one point, the council decided to drop it. And it stayed like that. We let it go [...]. And the mandate ended, just like that. Just with the notion that the scheme still hadn't managed to get off the ground, we still didn't have the funding, and we still didn't have the project [...]. [The] wine sector wasn't very enthusiastic anyway. We had the support of the Inter-professional Bordeaux Wine Committee (CIVB), but there wasn't much enthusiasm or back up from the wine growers and others." [POT]
\end{abstract}

\title{
3.2. THE WCTC PROJECT FINALLY TAKES OFF (2008-2016)
}

In 2008, thanks to the good results of the city of Bordeaux (growing population resulting in higher tax revenues, debt reduction, increase in overnight stays, development of river tourism, increase in airport traffic, etc.), ${ }^{9}$ Alain Juppé was re-elected and began his $4^{\text {th }}$ mandate. Soon after, he dug out the WCTC project once again. At this time, Bordeaux was drawing up an application to compete for the title of European capital of culture 2013. For the mayor of Bordeaux, it was an opportunity to take the WCTC project to another level, and it became a political priority for him, even if he still had to convince the other local authorities from opposing political camps to finance the project. From this point on, Alain Juppé got personally involved in the scheme, notably by stepping up the number of working meetings, and coerced a consensus for the project with a new budget of 63 million euros.

\footnotetext{
${ }^{9}$ The media regularly mentions the rebound of the town, known in the past as the sleeping beauty.
} 


\begin{abstract}
"The project was put back on the agenda at a time when Bordeaux, prompted by Alain Juppé, wanted to compete for the title of European capital of culture [...]. And in [this context] we dug up all the old files on the cultural wine centre [...]. The mayor wanted us to forge ahead with the centre, even though the other local authorities were somewhat lukewarm [...]. It's clear that you need a political leader who can drive the project through! [...]. From the moment it becomes part of a larger project, in other words, the 'Bordeaux, European capital of culture' project, and you shift from being a small scheme of [a few] million euros to something which amounts to [more than] 60, and, behind it all, you have a true project driver who says 'whatever happens, I'll see it through to the end,' at that point your mindset changes completely. And then you give yourself the resources to reach the goals you've set [...]. Certainly, from that point, we changed dimension completely. And it became a political issue, although at the beginning it wasn't really [...]. It's clear that Juppé's political will was decisive [...]. And I can see that in the end we got quite a few [people] on board. Most people [subscribed to the idea]." [CIVB1]
\end{abstract}

Despite Bordeaux's failure to be selected as European capital of culture in September 2008, the momentum did not end. In effect, the wine sector was hard hit by the financial crisis and requested public assistance. The need to build a cultural centre dedicated to wine became more urgent. The WCTC project thus became a flagship scheme for tourism in Bordeaux and the surrounding area, a way to attract tourists to the wine estates and so to promote wine tourism. Moreover, from 1995, the town underwent a major facelift and was ready to welcome a cultural centre like the WCTC (redevelopment of wharves, refurbished façades, reduction of bottlenecks by the introduction of the tramway, registration as a UNESCO world heritage site, etc.). This time, Alain Juppé called on the Bordeaux town councillor in charge of promoting the wine and wine tourism sector, a wine producer herself and formerly President of the Union des Grands Crus de Bordeaux (a highly influential club which includes 130 of Bordeaux's biggest vineyards). Closely linked to the world of wine, her presence enabled the project to get the sector's support. She asked Philippe Massol (former operational director of a major French tourist site) to take on the WCTC project. For the first time, a nine-person project team was formed (director, cultural director, science manager, artistic and stage set consultant, development manager, sales manager, etc.). It soon became obvious that this project would be on another scale compared to the previous draft projects, with a new site, a larger building, an audacious architectural design, a focus on the wine civilisation in general rather than simply on Bordeaux wines, a futuristic setting rather than one based on tradition, etc. (see below). With the backing of the wine sector professionals and virtually all the local 
authorities, ${ }^{10}$ the final pre-project plan submitted by Bordeaux council as the project owner was approved on 16 July 2012. The municipality agreed to invest 12.5 million euros and to cover part of the difference if any of the pledged co-financing failed to materialise. In November 2012, the WCTC was renamed the Cité des civilisations du vin (city of wine civilisations). The first stone was laid on 19 June 2013 and the centre is now scheduled to open in the first half of 2016.

\subsection{ANALYSIS OF PERSISTENCE IN THE WCTC PROJECT}

With Bordeaux council as the main stakeholder in the project ecology (Starkey et al., 2000), the chronological account, summarised in Figure 1 below, highlights the persistence of the stakeholders despite the many difficulties encountered by the WCTC scheme.

\section{[Insert Figure 1 about here].}

Our detailed analysis of the WCTC project persistence shows that the series of projects before $2008(\varphi 1)$ follow a certain pattern, while the post-2008 changes $(\varphi 2)$ constituted a real break with the past. ${ }^{11}$ In what follows, we structure our empirical data analysis through the different categories emanating from our dictionary of themes.

\section{Direct and indirect experience feedback}

The town counsellor entrusted with the project by the mayor of Bordeaux began by analysing the wine sector professionals' expectations. At that point, she made no attempt to review the work previously done by Catherine Arteau. Moreover, in the prefeasibility study drawn up in 2008 at Alain Juppé's request, she did not mention the earlier studies or the name of the

\footnotetext{
${ }^{10}$ Only Gironde council refused to take part in the scheme that it described as a white elephant given the social situation of most of the Gironde wine growers (Sud Ouest, 15 May 2012).

${ }^{11}$ The initial idea to develop wine tourism in the Bordeaux vineyards area remained the same throughout the project. The project therefore stayed within the same trajectory and symbolically retained the same name until 2012.
} 
cultural engineer. ${ }^{12}$ After Philippe Massol was hired, the second stage involved analysing the earlier projects to identify their strengths and weaknesses and to see how the WCTC project could be refocused. Philippe Massol managed to collect all the studies made from 1995 onwards, and also contacted Catherine Arteau for more information.

\begin{abstract}
"Once Philippe [Massol] had been hired, that was when we be began to ask real questions, [in particular with an] analysis of what had been done to date and all the pros and cons. What was good? What should be kept? What should be thrown out? A few studies had been made at the outset, [notably] on the previous schemes [...]. This was yet another project if you like. We took everything that was good from it. What had been done in the past was not wasted because we permeated ourselves with that project at the outset. And after, we said: 'That's not relevant anymore. That's not a good idea, because we're in a different era. That's good, we ought to keep it.' So it helped us, but it was just one of the aspects [among others]." [WPB]
\end{abstract}

As an indication of his interest in the documents collected, Philippe Massol gave them to the different experts involved in the scheme so that they could absorb the concepts. This included the agency in charge of defining the WCTC concept and the pre-programme. In this regard, the agency director stressed that the idea of wine civilisations, a central feature of his PowerPoint presentation in August 2009, came to him after consulting the earlier files.

"When I met Philippe [Massol], he gave me loads of files. He told me: 'This is what was in the boxes, it's been gathering dust for several years in Bordeaux!' So it was a very useful source of information [...]. The universe of wine was in it, for example ${ }^{13}$ [...]. [It was by sifting through] these documents that the concept of the wine centre, the civilisations of wine, was born! [The documents were] superfluous though ${ }^{14}$ - I have to say it - but seeing what the others had suggested helped me to get into the project! [...]. I really liked the idea of a wine universe." [CONSULT]

Reading through these different documents, the main conclusion drawn by the project team was that the WCTC had to reach a critical size, have an international dimension and a focus on the future rather than the prestigious past of Bordeaux wines if it was to interest tourists, industry professionals and elected officials. However, the study of the former projects' experience was very brief, and was barely discussed in the working group meetings on the

\footnotetext{
12 The term prefeasibility may appear surprising in view of all the other studies that had already been carried out on the project beforehand (cf. Table 2).

${ }^{13}$ In fact, the project defended by Catherine Arteau was called "Le Monde du Vin" (the world of wine).

14 The consultant emphasised the fact that there had been a lot of copy and paste between one study and another between 1995 and 2008, a sign of real continuity in the series of projects.
} 
WCTC scheme. ${ }^{15}$ For instance, some of today's key players have never heard of the association at the origin of the project (see above). In fact, the players in charge of the WCTC appeared far more interested in benchmarking other popular cultural and tourist attractions, especially from abroad (e.g.: the Guggenheim in Bilbao, the Guinness Storehouse in Dublin, the Heineken Experience in Amsterdam, etc.). Moreover, some choices were made because of the scientific content (setting, decor, etc.), directly inspired by looking around other attractions. Studying other ways of doing things also helped to back up certain radical options adopted for the WCTC, like the very striking architectural strategy, for example.

\begin{abstract}
"[The Guinness Storehouse] gets a million visitors a year. [We went to] visit it [...]. There's a sort of enormous circular ramp. As you go up the ramp, you gradually come across various stages that tell you the complete story of beer. It's very clever and it's also elegant. It's simple. And you never get bored at all. I found it incredible! [...]. It's a great success, if you like. So we went to analyse it. It helped us a lot [...]. In Shanghai, [...] you have the Urban Planning museum. It's fantastic [...]. It's a model of an enormous town and you play with the different buttons to see - with lights and everything - what's been demolished, what's been built, what's going to be built, etc. I found its ambitious, playful, learner-friendly and educational design really well done. And we tried to integrate all these ideas, if you like. Each time, we could draw from completely different areas. Just details [...].There were loads of ideas for the decor for instance! I often took photos [...]. And then said: 'yes, we have to have that,' 'no, we can't have that,' 'that's no good,' etc. [...]. In fact, we looked for ideas everywhere! We invented nothing!' [WPB]
\end{abstract}

\title{
Inter-project capitalisation, change and turnover of key players
}

In the current project, fragments of some of the key ideas introduced at the end of the $1990 \mathrm{~s}$ still remain. For instance, it was always evident that the WCTC had to be something other than a traditional wine museum. Similarly, right from the start, the WCTC was seen as a means to welcome visitors, help them to understand the vineyard in all its myriad forms, and promote other tourist sites in Bordeaux and the region. Finally, as already mentioned, the idea of the wine civilisation that is at the core of the current project was inspired by Catherine Arteau's "world of wine" concept. Nonetheless, despite this relative continuity over time, the WCTC project changed considerably after 2008. First, the people in charge of its operational aspects are no longer the same as the earlier project managers. Thus, former key players in the

\footnotetext{
${ }^{15}$ One member of the pilot committee told us: “As far as I'm concerned - but perhaps I'm wrong - in 25 years, no one thought it through [...]. I never looked at the earlier studies on the topic of wine because I didn't have time or couldn't be bothered [laughs]! I didn't bother to look back at the old files to see the earlier projects [...] the one about Chartrons, for example." [BUC]
} 
project were not invited to join the present discussions. In the same way, today's main players were not involved in the previous studies at all. The changeover to a new project manager was highly symbolic as, instead of a cultural engineer from Bordeaux and the daughter of a winegrower (Catherine Arteau), the new manager was a leisure-culture-tourism engineer from outside Bordeaux, and not a wine specialist (Philippe Massol). In fact, only one person knew the whole story of the project as she was at the origin of the creation of the association mentioned earlier. Today, she is part of a working group that oversees the contents of the WCTC project, but she appears "a bit detached from the current project." Moreover, she rejected the idea that she would be the "project memory," mainly because she declared that she had not been involved in all the different stages. Given the massive participant turnover, our respondents felt that the project really "began from scratch" in 2008. Philippe Massol spoke about a "blank page" or "virgin territory," suggesting that they had "wiped the slate clean." Catherine Arteau admits that the project "became something quite different" with the arrival of the new team and that it tells "another story," even if the name Wine Culture and Tourism Centre in Bordeaux continued to be used until the end of 2012.

\footnotetext{
"I think that we're starting from scratch. The only thing left from the original idea is that we must have something about wine in Bordeaux [...]. Now, we're beginning again with a new project [...]. So we've wiped the slate clean with a new team, a different brief, and partners making a financial contribution from the very outset." [LP1]
}

Among the major changes compared to the preceding project guidelines, we can first note the change in scale (cf. Table 3) initiated by Alain Juppé. The new idea was to build a "Wine Louvre" that would consolidate Bordeaux's position as a global wine capital. The municipality wanted to create a flagship cultural building which would act as a major tourist attraction for Bordeaux, like the Guinness Storehouse in Dublin. This change in scale in terms of budget, size and number of visitors reflected the stakeholders' increased commitment, especially that of Bordeaux council. In effect, in 2004, the council contributed between 1,525 and 1.75 million euros to the project, while in July 2012, the council picked up the bill for 
almost $20 \%$ of the scheme, in other words, 12.5 million euros. The shift in scale went hand in glove with the WCTC's new international dimension and its focus on wine civilisations. In other words, the idea was no longer to simply showcase the glory of Bordeaux's wine history and the prestigious history of a Bordeaux district (the Chartrons). The building (which has changed location ${ }^{16}$ is far more futuristic and less focused on tradition. This is reflected in particular by its pioneering architectural expression as the shape of the building calls to mind the movement of wine being swirled around in a glass, breaking away from the codes of $18^{\text {th }}$ century Bordeaux buildings, unlike Catherine Arteau's project which was designed to exploit the existing buildings so as to preserve the $18^{\text {th }}$ century heritage. This shift to the future is also expressed in the use of cutting-edge multimedia exhibits and technology.

\begin{abstract}
"It's not stuck in a time warp. It's not looking back at the past. It's not a cultural centre as it would have been with Chartrons. The space and the buildings alone show this [...]. It's a space that is dedicated to [the civilisation of] wine. And not only Bordeaux wine. We're not so much in Bordeaux as [in] 'Bordeaux, world capital of wine' [...]. We have the latest scene-setting technology [...]. [The] architecture is extremely audacious [...]. In fact, we're completely detached [from] the 'cult of the past.' At any rate, the focus is not only on showcasing the Bordeaux area. That's obvious! It's really the world of wine! [...]. [Before, we were] more in the framework of refurbishing a space [...]. We were very constrained by the site [...]. I think [in changing the site] it helped us to view the centre in its truly global dimension." [CIVB1]
\end{abstract}

Table 3 below summarises the main turning points of the project path in 2008 .

\title{
[Insert Table 3 about here].
}

\section{DISCUSSION}

Our findings from the case history (Denis et al., 2011) of the WCTC appear to confirm Lynn et al. (1996)'s arguments that persisting with a project is relevant when this choice is driven from the outset by a clear strategic vision on the part of the decision-makers. In the present case, we noted that the mayor of Bordeaux immediately saw the interest of the WCTC project for the Aquitaine wine industry. Over the course of time, however, he shifted from a position

\footnotetext{
${ }^{16}$ The museum left the historic town centre of Bordeaux and moved to the northern end of the regenerated port area. The change in site was inevitable. In effect, the WCTC project had taken too long and the firm in charge of the Chartrons redevelopment scheme could not keep the area free indefinitely.
} 
of adhesion to the project principle to a strong conviction that it was a genuinely interesting strategic challenge. We also show that the persistence of a latent organisation when confronted with past failures is appropriate if the central core of the project (Starkey et al., 2000), in our case embodied by the mayor, decides, at a given point in time, to publicly show political support for the scheme and to personally engage in its success. In other words, the strong and visible support of a central, emblematic (i.e. renowned and influential) public figure means that a consensus can be achieved, and that the most sceptical stakeholders can be convinced to come on board. Despite the former failures, this political determination effectively removed some of the uncertainty surrounding the project (Brockner, 1992; Lant et al., 1992), which consequently legitimised the increased commitment of all those who formed part of the project's ecology (Starkey et al., 2000). From this perspective, allocating more financial resources to an otherwise failed project may, in contrast to widely held opinions regarding escalation of commitment (Staw, 1976), prove to be an economically rational decision if the project becomes a true political priority. In effect, it was when the mayor of Bordeaux upped the stakes that the WCTC finally began to materialize. In short, if a project is judged as interesting but a failure, increased commitment should not necessarily be viewed as a form of escalation (Staw, 1976; Brockner, 1992), but may be seen as a strong political sign of the project's importance in the eyes of the decision-makers, triggering greater enthusiasm from the other stakeholders. Given that their credibility is at stake, charismatic leaders will go all out to make the project a success (the assessment of their action as a leader is closely linked to the project's success), thereby lending credibility to the actions undertaken. This ties in with two key ideas of the actor network theory, namely, that enlisting and mobilising stakeholders in a project (active support) is linked not only to the art of getting these people interested through fitting arguments, but also to the choice of good spokespeople (Akrich et al., 2002a, 2002b). In other words, stronger commitment to a project by charismatic leaders, 
designed to put a stop to controversy, may, according to this theory, be interpreted as a form of translation, a reformulation of a message, a fact or information. In short, the leader's ability to get his/her message across to potential allies (Akrich et al., 2002a) is a decisive factor in justifying persistence in a project. According to the vision of persistence as a multiparty event (Liang et al., 2014), we can also add that positive results obtained elsewhere by the decisionmaker - as was the case here with Alain Juppé (growing population, debt reduction, refurbished façades, etc.) - reinforce his/her leadership with stakeholders ${ }^{17}$ and, de facto, the legitimacy of the project he or she is defending (heuristic reasoning). In addition, these positive results reinforce the leader's self-efficacy (Jani, 2011) and intention to persist. Our first proposal is therefore that persisting in the event of failure makes sense if a charismatic leader is able, at a given moment, to create a consensus over what he/she sees as a strategically important project.

We should add that Alain Juppe's persistence must also be interpreted in terms of external factors that wholly changed the context of the project. For instance, in the present case, the urban planning policies in Bordeaux, in particular the arrival of the tramway in 2003 and the regeneration of the port area, completed in 2009 , subsequently made the emergence of a modern flagship cultural attraction like the WCTC possible. In the same way, the economic crisis in the wine industry legitimised the emergence of a major project designed to help wine producers in Aquitaine. In this case, the relatively recent interest of the latter in the concept of wine tourism justified the earmarking of more resources to the WCTC project, despite its past failures. As the wine industry is highly traditional and conservative, the wine professionals' change of heart regarding wine tourism gave Alain Juppé a strong signal, encouraging him to persist with the innovative project. This change in the professionals' attitude persuaded him that he now controlled a key exogenous factor in the project's success (Jani, 2011). This leads

\footnotetext{
${ }^{17}$ Recall that Alain Juppe has always improved its score for each new municipal election.
} 
us to reconsider existing work on persistence. In the literature, putting failure down to external (situational) rather than internal (dispositional) causes is assumed to short-circuit organisational learning and lead to a greater probability of persistence (Lant et al., 1992; Staw, 1981; Winch, 2013). For example, decision-makers maintain their key strategies as they put the failure down to bad luck or adverse conditions. The present study adopts a different perspective. In effect, our paper shows that awareness of the situational factors in a failure can help to justify persistence if the external environment changes. In other words, the ability to clearly identify the external causes of failure helps the stakeholders to find grounds for optimism if the socio-economic context changes. Moreover, our case study underscores the importance of choice opportunities (Cohen, March and Olsen, 1972) with regard to persistence. ${ }^{18}$ In the case of the WCTC, for example, the project's main activation and reactivation phases correlate with the start of each of the mayor of Bordeaux's mandates, which implies that local elections may be considered as choice opportunities. At the same time, the European Capital of Culture competition provided an opportunity to dig out the WCTC project once again. In short, persistence is appropriate if new choice opportunities arise to legitimise the pursuit or even the stepping up of previous efforts. In this sense, persisting with a project is only an opportune decision if the contextual factors change. By inference, this highlights the importance of timing in the case of persistence, as well as the need for time-out during the project path (Sydow, 2009) if the environment remains unchanged. In this regard, it is clear that the rebranding of Bordeaux (from sleeping beauty to an attractive tourist destination) played in favour of the project. In short, our second proposal is that persisting in the event of failure makes sense if the environmental conditions surrounding the project have changed and new choice opportunities appear.

\footnotetext{
${ }^{18}$ In the garbage can model "choice opportunities [...] are occasions when an organization is expected to produce behavior that can be called a decision" (Cohen et al, 1972: p. 3).
} 
Beyond the immediate external environment of the project, our paper also highlights a vicarious learning phenomenon. Specifically, our study indicates that persistence in a project may be viewed through the lens of indirect experiential learning dynamics (Kim and Miner, 2007). Thus, observations of similar projects that have had a certain degree of success - in our case, flagship cultural and tourist attractions for a town - legitimise the effort to pursue the project in question, while at the same time reshaping it (see below). Conversely, the conclusion at the end of this study that the impact of direct experiential learning is weak may surprise us, especially as the literature considers appropriate persistence in a project to be linked to the notion of an iterative, trial and error innovation process. Pursuing former efforts thus supposes a capitalisation of inter-project knowledge in order to continually improve (Van de Ven and Polley, 1992; Lynn et al., 1996). However, the present case indicates, on the contrary, that persistence can be justified for a latent organisation (Starkey et al., 2000) precisely because there is, at a given moment, a form of organisational unlearning (Hedberg, 1981) that goes beyond simple adaptive persistence (Cunha, Rego, Clegg and Lindsay, 2015). While the innovation path remained the same (Nemanich et al., 2007; Suarez, 2014), in other words, a wine-based cultural and tourism centre to develop wine tourism, the project effectively made a clean break with the past after 2008. There is also deliberate discontinuity in the project path (Sydow, 2009). More specifically, persisting only made sense in the present case because the decision was made to "forget the former projects" and "begin again from scratch," which implied ignoring, at least in part, the inter-project interdependencies (Nemanich et al., 2007). This finding calls into question the idea of a direct experiential learning dynamic (Levitt and March, 1988). It also runs counter to the view of persistence being associated with inertia or the inability of players to unlearn (Finkelstein and Hambrick, 1990; Hambrick, Geletkanycz and Fredrickson, 1993; Kisfalvi, 2000). In effect, in the case of the WCTC, the programme was only pushed forward because the actors decided to dispense 
with much of the previously accumulated knowledge. Persistence and change are therefore not contradictory. The present study also suggests that such enhanced commitment should not be considered a decision-making error like escalation of commitment (Staw, 1976), if it is prompted by a shift in the project's content, which may be linked to the arrival of new players. In this respect, our study contradicts the view put forward by Finkelstein and Hambrick (1990), who argued that persistence is often due to the fact that the decision-makers have been with the organisation for many years. Indeed, in the case of the WCTC, the high turnover of project coordinators did not prevent the persistence of the latent organisation. On the other hand, the turnover we observed is linked to a specific type of persistence combining continuity and change. Thus, we disagree with Garud et al. (2010) who argue that continuity and change cannot be considered as processes driven by similar dynamics. In short, if the experiential learning underpinning persistence is more indirect than direct, this appears to be linked to the fact that the success of other projects is more important with regard to learning than a past failure of the said project. Players' disregard of past failure may thus be envisaged as a form of cognitive simplification, especially as interest in successful ventures is widely acknowledged in the management literature (Kim and Miner, 2007). Finally, our third proposal in this study is that persisting in the event of failure makes sense if the project, while remaining on track, is subject to a change of content and is legitimised by the success of other similar projects.

\section{CONCLUSION}

The aim of this study was to identify the conditions for appropriate persistence with regard to managing a project. Thus, we conducted a longitudinal study on the Wine Culture and Tourism Centre project in Bordeaux that spanned a period of almost 20 years. The temporal breakdown (Langley, 1999; Langley et al., 2013) enabled us to gain new insights into the 
boundary between obstinacy (inappropriate persistence) and tenacity (appropriate

persistence). At the same time, our study suggests that persisting with a project in the event of failure can make sense: 1) if an influential and well-known leader makes the project a strategic priority and is able to command a consensus between all the stakeholders, 2) if the project's external environment changes, with new choice opportunities emerging to revive the project, and 3) if the project makes a clean break with past attempts and is consolidated in terms of strategic vision by the success of similar projects. This theoretical interpretation of persistence has a strongly prescriptive take as our propositions aim, to some extent, to help decision-makers make the right decisions when faced with a project failure (i.e. to pursue the venture or to stop in time). In this sense, the various elements of our discussion can be seen as contributions to good management since they are clearly action-focused. However, our study also has certain limitations. For Yin (1990), focusing on just one case can be useful when an in-depth analysis of the study in question gives us theoretical insights into a relatively poorly understood issue (in our case, appropriate persistence). However, the focus on a single case restricts the external validity of our study. Indeed, as Winch (2013: 727) argued, "there is no 'typical' major project $[\ldots]$. In terms of both the project mission [...] and the socio-economic context in which that mission is being delivered all major projects are different." This is all the more important given that our case study is highly specific. First, we study a project dealing with wine in a town internationally reputed for its wine. Second, it is a public-private project managed by a latent organisation (Starkey et al., 2000) whose form changed over time. It would therefore be interesting to compare the WCTC (63 million euros) programme with that of the Institut des Sciences de la Vigne et du Vin (30 million euros), constructed on the outskirts of Bordeaux, which took almost as long as the WCTC before completion. An intercase comparison could thus help us to identify analogies and links between these two 
ambitious wine industry projects, which would boost the external validity of our conclusions de facto.

\section{ACKNOWLEDGEMENTS}

We would like to express our sincere thanks to Philippe Massol for allowing us to conduct this research on the Wine Culture and Tourism Centre. 


\section{REFERENCES}

Akrich, M., Callon, M., \& Latour, B. (2002a). The Key to Success in Innovation Part I: The Art of Interessement. International Journal of Innovation Management, 6(2), 187-206.

Akrich, M., Callon, C., \& Latour, B. (2002b). The Key to Success in Innovation Part II: The Art of Choosing Good Spokespersons. International Journal of Innovation Management, 6(2), 207-225.

Ammann, M., Huber, O., \& Schmid, M. (2013). Hedge Fund Characteristics and Performance Persistence. European Financial Management, 19(2), 209-250.

Babineaux, R., \& Krumboltz, J. (2013). Fail Fast, Fail Often: How Losing Can Help You Win, Tarcher.

Bartoloni, E. (2012). The persistence of innovation: a panel data investigation on manufacturing firms. International Review of Applied Economics, 26(6), 787-810. Bredin, D., Cuthbertson, K., Nitzsche, D., \& Thomas, D. (2014). Performance and performance persistence of UK closed-end equity funds. International Review of Financial Analysis, 34, 189-199.

Biyalogorsky, E., Boulding, W., \& Staelin, R. (2006). Stuck in the Past: Why Managers Persist with New Product Failures. Journal of Marketing, 70(2), 108-121.

Bowen, M. (1987). The Escalation Phenomenon Reconsidered: Decision Dilemmas or Decision Errors? Academy of Management Review, 12(1), 52-66.

Brockner, J. (1992). The Escalation of Commitment to a Failing Course of Action: Toward Theoretical Progress. Academy of Management Review, 17(1), 39-61.

Cheng, Y.-T., \& Van de Ven, A. (1996). Learning the Innovation Journey: Order out of Chaos? Organization Science, 7(6), 593-614.

Chesbrough, H. (2003). Open Innovation: The New Imperative for Creating and Profiting from Technology, Boston: Harvard Business School Press. 
Choo, C. (2005). Information Failures and Organizational Disasters. MIT Sloan Management Review, 46(3), 8-10.

Cohen, M., March, J., \& Olsen, J. (1972). A Garbage Can Model of Organizational Choice. Administrative Science Quarterly, 17(1), 1-25.

Cumming, D., Dai, N., Haß, L., \& Schweizer, D. (2012). Regulatory induced performance persistence: Evidence from hedge funds. Journal of Corporate Finance, 18(5), 1005-1022. Cunha, M., Rego, A., Clegg, S. \& Lindsay, G. (2015). The dialectics of serendipity. European Management Journal, 33(1), 9-18.

Delios, A., Inkpen, A., \& Ross, J. (2004). Escalation in International Strategic Alliances. Management International Review, 44(4), 457-479.

Denis, J., Dompierre, G., Langley, A., \& Rouleau, L. (2011). Escalating indecision: Between reification and strategic ambiguity. Organization Science, 22(1), 225-244.

Dobusch, L. \& Schüßler, E. (2012). Theorizing path dependence: a review of positive feedback mechanisms in technology markets, regional clusters, and organizations. Industrial and Corporate Change, 22(3), 617-647.

Drummond, H. (2014). Escalation of commitment: when to stay the course? The Academy of Management Perspectives, 28(4), 430-446.

Drummond, H. (1996). Escalation in decision-making: The tragedy of Taurus. Oxford, UK: Oxford University Press.

Finkelstein, S., \& Hambrick, D. (1990). Top-Management-Team Tenure and Organizational Outcomes: The Moderating Role of Managerial Discretion. Administrative Science Quarterly, 35(3), 484-503.

Ganter, A., \& Hecker, A. (2013). Persistence of innovation: Discriminating between types of innovation and sources of state dependence. Research Policy, 42(8), 1431-1445. 
Garud, R., Kumaraswamy, A., \& Karnøe, P. (2010). Path Dependence or Path Creation? Journal of Management Studies, 47(4), 760-774.

Gioia, D., Corley. K., \& Hamilton, A. (2012). Seeking Qualitative Rigor in Inductive Research: Notes on the Gioia Methodology. Organizational Research Methods, 16(1), 15-31. Glode, V., \& Green, R. (2011). Information spillovers and performance persistence for hedge funds. Journal of Financial Economics, 101(1), 1-17.

Hambrick, D., Geletkanycz, M., \& Fredrickson J. (1993). Top executive commitment to the status quo: Some tests of its determinants. Strategic Management Journal, 14(6), 401-418. Hedberg, B. (1981). How Organizations Learn and Unlearn. In Paul Nystrom and William Starbuck (Eds.) Handbook of Organizational Design - Vol. 1: Adapting organizations to their environments, New York: Oxford University Press, pp. 8-27.

Heng, C.-S., Tan, B., \& Weib, K-K. (2003). De-escalation of commitment in software projects: Who matters? What matters? Information \& Management, 41(1), 99-110. Hochberg, Y., Ljungqvist, A., Vissing-Jørgensen, A. (2014). Informational Holdup and Performance Persistence in Venture Capital. Review of Financial Studies, 27(1), 102-152. Howell, J., Shea, C., \& Higgins, C. (2005). Champions of product innovations: Defining, developing, and validating a measure of champion behavior. Journal of Business Venturing, 20(5), 641-661.

Jani, A. (2011). Escalation of commitment in troubled IT projects: Influence of project risk factors and self-efficacy on the perception of risk and the commitment to a failing project. International Journal of Project Management, 29(7), 934-945.

Kim, J.-Y., \& Miner, A. (2007). Vicarious Learning from the Failures and Near-Failures of Others: Evidence from the US Commercial Banking Industry. Academy of Management Journal, 30(2), 687-714. 
Kisfalvi, V. (2000). The Threat of Failure, the Perils of Success and CEO Character: Sources of Strategic Persistence. Organization Studies, 21(3), 611-639.

Langley, A., Smallman, C., Tsoukas, H., \& Van de Ven, A. (2013). Process Studies of Change in Organization and Management: Unveiling Temporality, Activity and Flow. Academy of Management Journal, 58(1), 1-13.

Langley, A. (1999). Strategies for theorizing from process data. Academy of Management Review, 24(4), 691-710.

Lant, T., Milliken F., \& Batra, B. (1992). The role of managerial learning and interpretation in strategic persistence and reorientation: An empirical explanation. Strategic Management Journal, 13(8), 585-608.

Levitt, B., \& March, J. (1988). Organizational Learning. Annual Review of Sociology, 14(3), 319-340.

Liang, B., Kale, S., \& Cherian, J. (2014). Is the future static or dynamic? The role of culture on escalation of commitment in new product development. Industrial Marketing Management, 43(1), 155-163.

Lynn, G., Morone J., \& Paulson, A. (1996). Marketing and Discontinuous Innovation: The Probe and Learn Process. California Management Review, 38(3), 8-37.

Maidique, M., \& Zirger, B. (1985). The New Product Learning Cycle. Research Policy, 14(6), 299-313.

March, J., \& Shapira, Z. (1987). Managerial Perspectives on Risk and Risk Taking. Management Science, 33(11), 1404-1418.

Meyers, P., \& Wilemon, D. (1989). Learning in New Technology Development Teams. Journal of Product Innovation Management, 6(2), 79-88.

Miles, M., \& Huberman, A. (1994). Qualitative Data Analysis: An Expanded Sourcebook, $2^{\text {nd }}$ edition, Thousand Oaks, CA: Sage Publications. 
Nemanich, L., Keller, R., \& Vera, D. (2007). Managing the exploration/exploitation paradox in new product development: how top executives define theirs firm's innovation trajectory. International Journal of Innovation and Technology Management, 4(3), 351-374

Northcraft, G., \& Wolf, G. (1984). Dollars, Sense, and Sunk Costs: A Life Cycle Model of Ressource Allocation Decisions. Academy of Management Review, 9(2), 225-234.

Raymond, W., Mohnen, P., Palm, F., \& Schim van der Loeff, S. (2010). Persistence of innovation in Dutch manufacturing: is it spurious? The Review of Economics and Statistics, 92(3), 495-504.

Roper, S., \& Hewitt-Dundas, N. (2008). Innovation persistence: Survey and case-study evidence. Research Policy, 37(1), 149-162.

Ross, J., \& Staw, B. (1993). Organizational escalation and exit: lessons from the Shoreham Nuclear Power Plant. Academy of Management Journal, 36(4), 701-732.

Ross, J., \& Staw, B. (1986). Expo 86: an Escalation Prototype. Administrative Science Quarterly, 31(2), 274-297.

Royer, I. (2003). Why Bad Projects Are So Hard to Kill. Harvard Business Review, 81(2), 4856.

Royer, I. (2001). Stopping-Champions of Failing Projects. Best Paper Proceedings, Academy of Managament Conference, Washington D.C., 3-8 August 2001 (Sage-Louis R. Pondy Award for the Best Paper Based Upon a Dissertation).

Sandelands, L., Brockner, J., \& Glynn, M. (1988). If at First You Don't Succeed, Try, Try Again: Effects of Persistence-Performance Contingencies, Ego Involvement, and Self-Esteem on Task Persistence. Journal of Applied Psychology, 73(2), 208-216.

Schaumberg, R., \& Wiltermuth, S. (2014). Desire for a positive moral self-regard exacerbates escalation of commitment to initiatives with prosocial aims. Organizational Behavior and Human Decision Processes, 123(2), 110-123. 
Schon, D. (1963). Champions for Radical New Inventions. Harvard Business Review, 41(2), $77-86$.

Sleesman, D., Conlon, D., McNamara, G., \& Miles, J. (2012). Cleaning up the big muddy: a meta-analytic review of the determinants of escalation of commitment. Academy of Management Journal, 55(3), 541-562.

Starkey, K., Barnatt, C., \& Tempest, S. (2000). Beyond Networks and Hierarchies: Latent Organizations in the U.K. Television Industry. Organization Science, 11(3), 299-305. Staw, B. (1981). The Escalation of Commitment to a Course of Action. Academy of Management Review, 6(4), 577-587.

Staw, B. (1976). Knee-Deep in the Big Muddy: a Study of Escalating Commitment to a Course of Action. Organizational Behavior and Human Performance, 16(1), 27-44.

Staw, B., \& Ross, J. (1987). Behavior in Escalation Situations: Antecedents, Prototypes, and Solutions. In Larry Cummings and Barry Staw (Eds.) Research in Organizational Behavior, Greenwich: JAI Press, 9, pp. 39-78.

Suárez, D. (2014). Persistence of innovation in unstable environments: Continuity and change in the firm's innovative behavior. Research Policy, 43(4), 726-736.

Sydow, J. (2009). Path Dependencies in Project-Based Organizing: Evidence from Television Production in Germany. Journal of Media Business Studies, 6(4), 123-139.

Thomke, S., von Hippel, E., \& Franke, R. (1998). Modes of Experimentation: An Innovation Process and Competitive Variable. Research Policy, 27(3), 315-332.

Townsend, W. (2010). Innovation and the value of failure. International Journal of Management \& Marketing Research, 3(1), 75-84.

Triguero, Á., \& Córcoles, D. (2013). Understanding innovation: An analysis of persistence for Spanish manufacturing firms. Research Policy, 42(2), 340-352. 
Van de Ven, A., \& Polley, D. (1992). Learning while Innovating. Organization Science, 3(1), 92-115.

Van Oorschot, K., Akkermans, H., Sengupta, K., \& van Wassenhove, L. (2013). Anatomy of a decision trap in complex new product development projects. Academy of Management Journal, 56(1), 285-307.

Vit, G. (2011). Competing logics: Project failure in Gaspesia. European Management Journal, 29(3), 234-244.

Walter, A., Parboteeah, K., Riesenhuber, F., \& Hoegl, M. (2011). Championship Behaviors and Innovations Success: An Empirical Investigation of University Spin-Offs. Journal of Product Innovation Management, 28(4), 586-598.

Winch, G. (2013). Escalation in major projects: Lessons from the Channel Fixed Link. International Journal of Project Management, 31(5), 724-734

Yin, R. (1990). Case Study Research: Design and Methods, Newbury Park, Sage. 